\title{
Purification of Gamma Glytamyl Transferase and Study Some Biochemical Variables in Sera Patients with Hepatitis B and C in Kirkuk City
}

\author{
Ibrahim Hadi Salih ${ }^{1,}$ Sayran S. Saleh ${ }^{2}$ \\ ${ }^{1}$ M. Sc. Chemistry Student. College of Science, Kirkuk University, Iraq, \\ ${ }^{2}$ Prof. Dr. Biochemistry. College of Science, Kirkuk University, Iraq
}

\begin{abstract}
Hepatitis B and C are the most frequent causes of chronic hepatitis diseases in the world. A cross sectional study was carried out in Kirkuk city from 17th of November 2019 to 25th of February 2020 . The number of hepatitis patients under study was 80 hepatitis patients, 44 with hepatitis B (14 acute and 30 chronic) and 36 with hepatitis $\mathrm{C}$ (11 acute and 25 chronic) Their ages were between 20-70 years old. These patients admitted to Hepatology and Gastroenterology Center of Azadi Teaching Hospital and Kirkuk General Hospital and The control group matched the patients group included 30 individuals who were apparently healthy who were conducted in this study to determine the level of activity of the enzyme (GGT) as well as to determine the level of a number of biochemical variables (ALT, AST, ALP, TSB, CRP, AFP) in both healthy subjects and patient group with acute and chronic viral hepatitis $\mathrm{B}$ and $\mathrm{C}$. The results showed that there was significant increase in the activity of the GGT enzyme in patients with P-value $(\mathrm{p} \leq 0.01)$ compared to control group. The present study showed that there was significant increase in the levels of (ALT, AST.ALP, TSB) in the blood serums of patients with acute hepatitis B and C compared to chronic and the healthy group. The present study also included the purification and partial isolation of the enzyme (GGT) and find the approximate molecular weight for it, that was purified from the blood serum of patients with hepatitis B and C and control group by using ammonium sulfate, Dialysis and gel filtrationchromatography with sephadex (G-150) to separate the enzyme from other proteins. The degree of purification in type C was (31.2) times, type B (27) times, and with healthy (30.2) times. The highsingle peak were used to determine the approximate molecular weight of the enzyme, and using the gel filtration technique. The approximate molecular weight of the enzyme (GGT) was up to $(371,000-346,000-316,000)$ Dalton for healthy and hepatitis C and B patients, respectively. In acute and chronic viral hepatitis B and C, there was a positive correlation between the efficacy of (GGT) and the efficacy of GPT, CRP and AFP. The study showed that there was significant increase in the activity of the GGT enzyme in patients compared to control group. The results showed in Table 3 that there was significant increase in the activity of the ALT enzyme in patients compared to control group. After performing the process of separating and purifying the GGT enzyme from the serum of patients with viral hepatitis B and C, using $40-60 \%$ of ammonium sulfate and after obtaining the required purity separating it from the rest of the components of the blood serum, the activity of the GGT enzyme was measured and it was found to have overall effectiveness in patients with hepatitis Liver $\mathrm{C}$ was $(0.282)$ and the number of purification times was (1.63) times and the specific effectiveness was (1843). Hepatitis B was (3.5) times, and the results from the dialysis process of the precipitate resulting from the saline precipitation process showed an increase in the specific activity of the enzyme GGT, so it was (3.4) for healthy people, (3.521) for patients with HCV and (4.3) HBsAg. Then he used gel filtration chromatography using the gel (Sephadex G-150), the results showed that a single protein beam appeared, which is highly effective and has a degree of purification reaching (30.2) And (31.2) and (27) times for GGT enzyme separated by gel filtration technique when the protein solution obtained from the blood serum of healthy subjects and patients with viral hepatitis is passed from the separation column containing gel (G-150).
\end{abstract}

Keywords: Gamma GlytamylTransferase; HCV; HBV; Kirkuk; Liver enzymes. 


\section{Introduction}

Several enzymes act as catalysts in a specific biochemical reaction that leads to the normal state and the maintenance of regular balance in the body. Any changes in the enzyme level in the body could indicate a specific abnormality in the body. The enzyme Gamma Glutamyl Transferase (GGT) is a hepatic and biliary enzyme with a molecular weight of (68000) Dalton that is synthesized by hepatocytes as well as by the epithelial cells of the bile ducts ${ }^{1}$, and it is a twomolecular glycoprotein, the large secondary unit and the small secondary unit are associated with a non-covalent 2. The GGT enzyme (EC2.3.2.2) is one of the main antioxidants in many of the body's defense mechanisms 3. It plays a key role in the metabolism and metabolism of glutathione ${ }^{4}$. it is classified within the enzymes that transport the peptide (Transpeptidase), as it stimulates the process of transferring the Gamma Glutamyl group of peptides and compounds that contain this group to some receptors that form the main substance Substrate or some amino acids or peptides or even water A simple decomposition process takes place.

Gamma-glutamyl-X + acceptor Gamma-glutamylacceptor $+\mathrm{X}$

It also has an important role in the liver, and it has other functions in the body as a transporter molecule, helping to transport other molecules around the body, such as glutathione, to a receptor that may be an amino acid, peptide, or water ${ }^{5}$. The GGT enzyme is present in the cell membranes of many tissues ${ }^{6}$ and is located on the outer surface of the plasma in almost all cells, but it is mainly involved in the epithelial tissues with their secretory and absorptive functions ${ }^{7}$, and includes the kidneys, bile duct, pancreas, gallbladder, spleen, heart., Brain, and seminal vesicles ${ }^{8}$. In adult liver, the enzyme (GGT) is found in the bile duct from hepatocytes and in gallbladder cells and is responsible for secreting bile into the bile duct ${ }^{9}$. Glutathione is the basis for the physiological enzyme (GGT) in mammals and The relationship between glutathione and GGT is presumed to be a means of supplying the liver with cysteine and Glycin.

\section{Materials and Method}

Thirty samples were collected from the blood of healthy people of varying ages from (20-50) years, These samples were collected by blood donors. (80) samples were collected from the blood of patients infected with viral hepatitis $(\mathrm{B}, \mathrm{C})$ after they were diagnosed by specialized doctors in the lobbies of the digestive system and the public health laboratory in Kirkuk. The hepatitis patients under study was 44 with hepatitis B (14 acute and 30 chronic) and 36 with hepatitis $C$ (11 acute and 25 chronic) Their ages were between 20-70 years old, The samples collection period is from 11/17/2019 to $2 / 25 / 2020$.

Estimation of GGT Activity in Serum: The basic principle of this method is known as Szasz, A kinetic chromatometric method for determining GGT activity ${ }^{10}$. The interaction can be explained as follows: This process liberates the compound (5-amino-2-nitrobenzoate, which can be measured at $405 \mathrm{~nm}$ ). The increase in absorption of this compound at this wavelength is directly related to the increase in GGT activity. Where $1000 \mu \mathrm{mol}$ of puffer is mixed with $100 \mu \mathrm{mol}$ of serum and incubated at a temperature of 37 for a minute, then $(250 \mu \mathrm{mol})$ of the base material is added to the mixture and incubated for a minute, then the absorbance is recorded at (405 nm) within 3 minutes.

Separation and purification of Gamma-Glutamyl Transferase (GGT) f: Ammonium sulfate is the first stage in the purification process during which the proteins present in the serum are deposited, depending on the degree of saturation of the serum with ammonium sulfate ${ }^{13}$. Where $(1.88 \mathrm{gm})$ of ammonium sulfate was added slowly with constant stirring to $(4.7 \mathrm{ml})$ of serum over a period of 60 minutes at low temperatures in order to obtain a saturation rate of $(40 \%)$. The filtrate was collected and placed in a centrifuge cooled at a temperature of $\left(4^{\circ} \mathrm{C}\right)$ and for a period of (20 minutes) the filtrate was taken and an ammonium sulfate (2.4 gm) was added to obtain a saturation rate of $(60 \%)$, then It was centrifuged at (14600 xg) for (20 minutes) to obtain the precipitate, the precipitate dissolved in $(\mathrm{mL})$ of $(0.125 \mathrm{M})$ Tris-HCl with a $\mathrm{pH}$ of $(8.3)$. Then it is placed in a centrifuge at a speed $(14600 \mathrm{xg})$ for a period of (20 minutes) at $\left(4^{\circ} \mathrm{C}\right)$, after which the total protein concentration is measured.

The dissolved protein is placed in the hemodialysis bag membrane after measuring GGT activity and protein concentration, and the pouch is immersed in buffer solution (HCl-Tris $0.125 \mathrm{M}$ ).) From a $\mathrm{pH}$ of 8.3. The solution is changed from time to time for an entire night. This step is performed at $\left(4^{\circ} \mathrm{C}\right)$ to maintain GGT activity. 
Gel filtration is also used as a method for estimating the approximate molecular weight of protein substances ${ }^{14}$. The Laemmli method was used to prepare electrolyte separation gel with modifications using $10 \%$ acrylamide gel and Coomassie bright blue ${ }^{15}$.

\section{Results}

The study showed that there was significant increase in the activity of the GGT enzyme in patients compared to control group.

Table 1: GGT enzyme level in acute and chronic hepatitis $C$ and $B$ patients and the control group.

\begin{tabular}{|l|c|c|c|}
\hline \multirow{2}{*}{ Studied groups } & N & GGT (U/L) & \multirow{2}{*}{ P. value } \\
\cline { 2 - 3 } & & Mean \pm SD & $202.4 \pm 52.0$ \\
\hline Patients with acute hepatitis C & 10 & $76.68 \pm 10.53$ & \\
\hline Patients with chronic hepatitis C & 14 & $192.07 \pm 26.04$ & $<0.01$ \\
\hline Patients with acute hepatitis B & 30 & $63.47 \pm 15.64$ & \\
\hline Patients with chronic hepatitis B & 30 & $40.43 \pm 15.29$ & \\
\hline Control group & & \\
\hline
\end{tabular}

The results showed in Table 3 that there was significant increase in the activity of the ALT enzyme in patients compared to control group, Table 2.

Table 2: GPT enzyme level in acute and chronic hepatitis $C$ and B patients and control group.

\begin{tabular}{|l|c|c|c|}
\hline \multirow{2}{*}{ Studied groups } & \multirow{2}{*}{ N } & ALT (U/L) & \multirow{2}{*}{ P. value } \\
\cline { 2 - 3 } & & Mean \pm SD & \\
\hline Patients with acute hepatitis C & 10 & $671.3 \pm 164.1$ & \multirow{2}{*}{$\mathrm{P}<0.01$} \\
\hline Patients with chronic hepatitis C & 25 & $34.04 \pm 8.18$ \\
\hline Patients with acute hepatitis B & 14 & $606.0 \pm 151.6$ & \\
\hline Patients with chronic hepatitis B & 30 & $27.00 \pm 7.05$ & \\
\hline Control group & 30 & $14.96 \pm 6.91$ & \\
\hline
\end{tabular}

Proteins were precipitated from their protein solution by removing the solvent to make them insoluble. After performing the process of separating and purifying the GGT enzyme from the serum of patients with viral hepatitis B and C, using $40-60 \%$ of ammonium sulfate and after obtaining the required purity separating it from the rest of the components of the blood serum, the activity of the GGT enzyme was measured and it was found to have overall effectiveness in patients with hepatitis Liver $\mathrm{C}$ was $(0.282)$ and the number of purification times was (1.63) times and the specific effectiveness was (1.843) as shown in the table (3-6). In hepatitis B patients, the overall effectiveness of GGT enzyme was found (0.27), the number of purification times (1.63), and the specific effectiveness (2.077), as shown in Table (3-7). The enzyme was concentrated and a degree of purity was obtained and the salts were eliminated during the separation process by membrane sorting by Tris- $\mathrm{HCl}$ with an acidic function of $\mathrm{PH}$ (8.3). Hepatitis B was (3.5) times, and the results from the dialysis process of the precipitate resulting from the saline precipitation process showed an increase in the specific activity of the enzyme GGT, so it was (3.4) for healthy people, (3.521) for patients with HCV and (4.3) HBsAg. Then he used gel filtration chromatography using the gel (Sephadex G-150), the results showed that a single protein beam appeared as shown in Figures (3$3),(3-4)$ and (3-5), which is highly effective and has a degree of purification reaching (30.2) And (31.2) and (27) times for GGT enzyme separated by gel filtration technique when the protein solution obtained from the blood serum of healthy subjects and patients with viral hepatitis is passed from the separation column containing gel (G-150). 


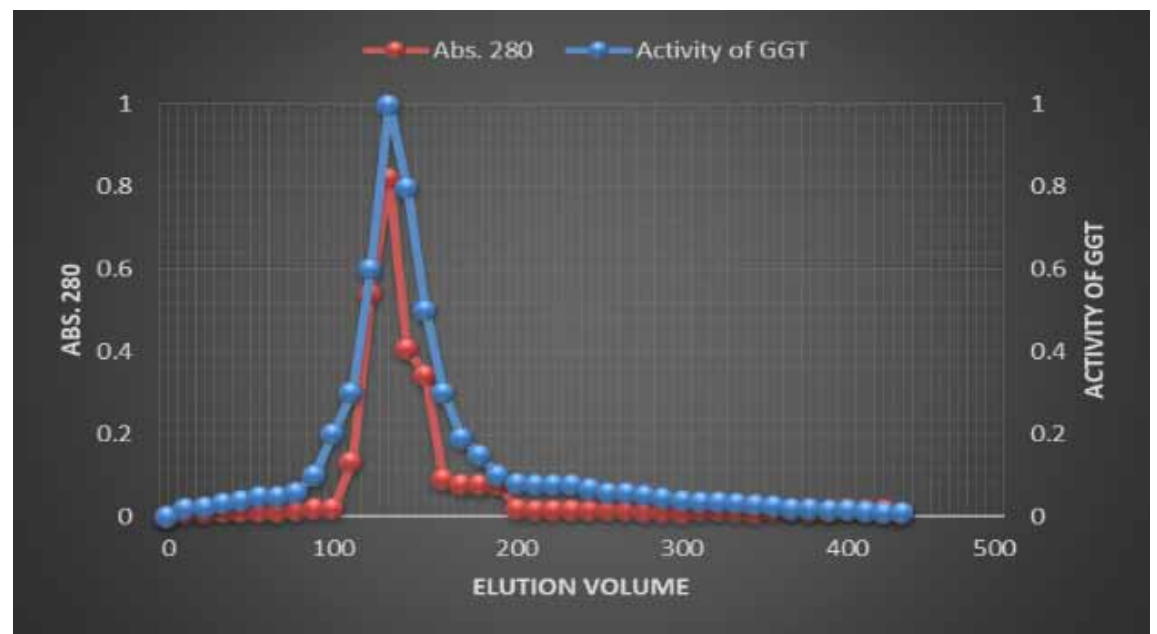

Figure 1: The profile shows the demonstration of the highly effective GGT protein packet from the gel filtrate column of the healthy blood serum.

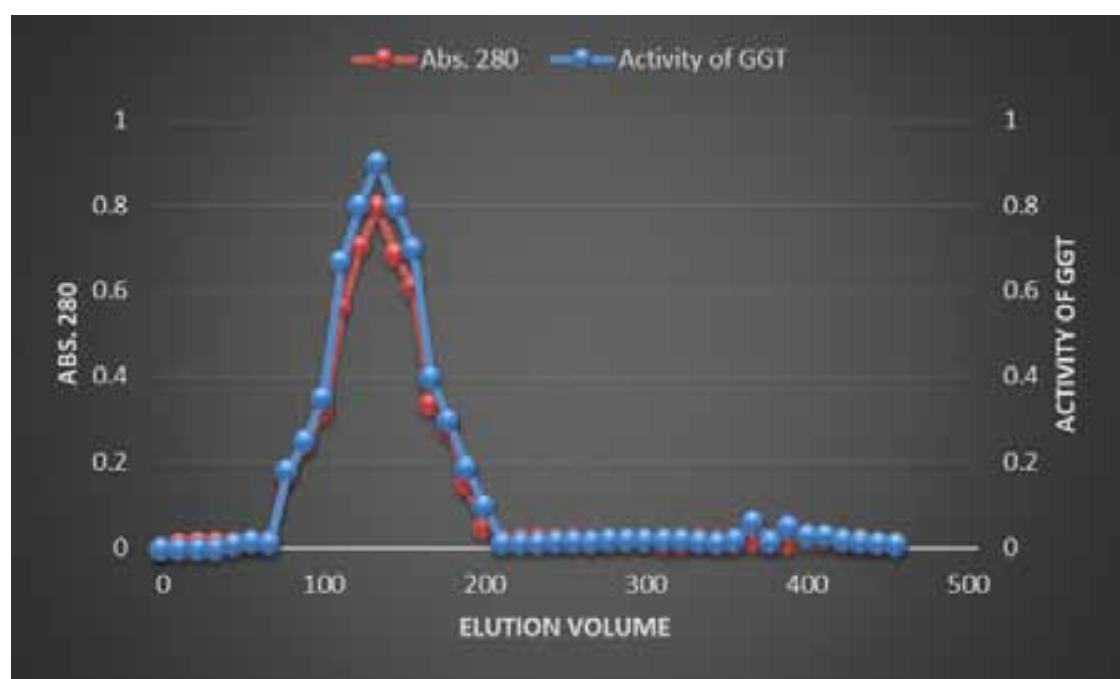

Figure 2: The profile Rogan shows the high-potency GGT protein packet from the gel-filtration column of the serum of patients with viral hepatitis $C$.

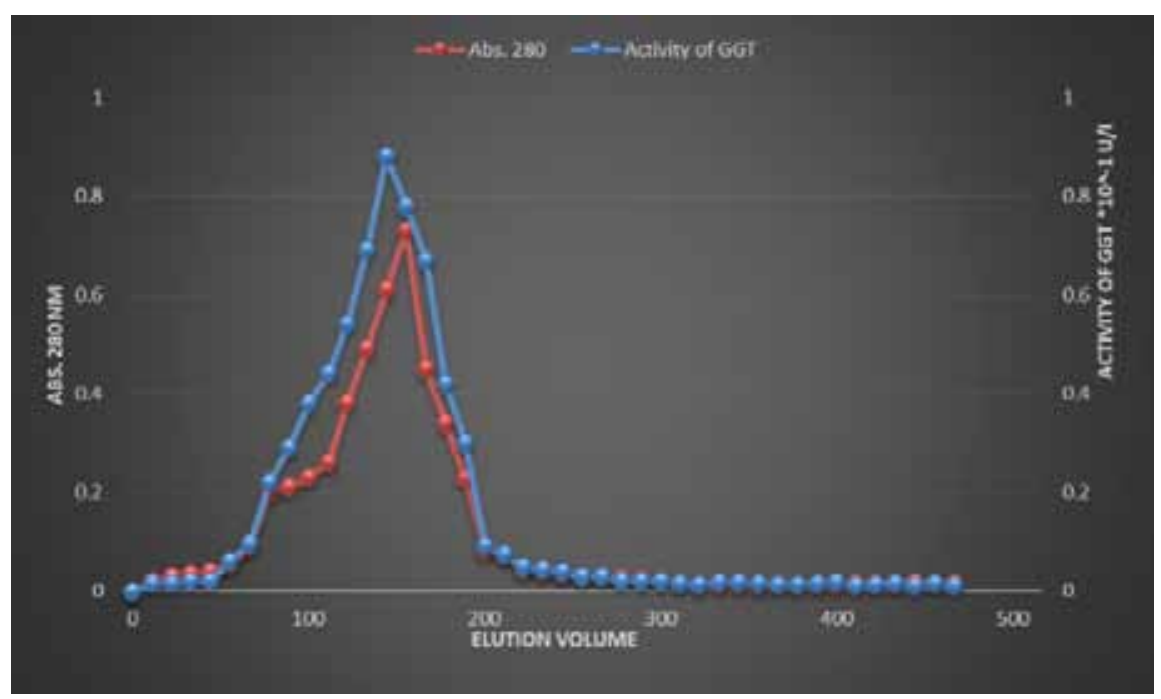

Figure 3: The profile shows the Rogan of the high-activity GGT protein packet from the gel filtrate column of the serum of patients with hepatitis $B$. 
Table 5: Steps of GGT enzyme purification from blood serum of healthy subjects

\begin{tabular}{|l|c|c|c|c|c|c|c|c|}
\hline Purification Step & Volume (L) & $\begin{array}{c}\text { Protein } \\
\text { Conc (g/L) }\end{array}$ & $\begin{array}{c}\text { Total } \\
\text { Protein (g) }\end{array}$ & $\begin{array}{c}\text { Enzyme } \\
\text { Activity } \\
\text { (U/L) }\end{array}$ & $\begin{array}{c}\text { Total } \\
\text { Activity U }\end{array}$ & $\begin{array}{c}\text { Specific } \\
\text { Activity (U/ } \\
\text { mg) }\end{array}$ & $\begin{array}{c}\text { Fold of } \\
\text { Purification }\end{array}$ & $\begin{array}{c}\text { Yield 100 } \\
\text { \% }\end{array}$ \\
\hline Serum & 0.005 & 61.2 & 0.306 & 51 & 0.25 & 0.817 & 1 & 100 \\
\hline $\begin{array}{l}\text { Precipitatioby Ammonium } \\
\text { sulphate 60\% }\end{array}$ & 0.0048 & 24.1 & 0.115 & 40 & 0.192 & 1.67 & 2 & 76.8 \\
\hline Dialysis & 0.0032 & 12.2 & 0.039 & 42 & 0.134 & 3.4 & 4.16 & 53.6 \\
\hline $\begin{array}{l}\text { Gel Filtration Sephadex } \\
\text { G-150 }\end{array}$ & 0.0027 & 1.9 & 0.005 & 45 & 0.121 & 24.2 & 30.2 & 48 \\
\hline
\end{tabular}

Table 6: Steps for GGT enzyme purification from blood serum for people with viral hepatitis C.

\begin{tabular}{|l|c|c|c|c|c|c|c|c|}
\hline Purification Step & Volume (L) & $\begin{array}{c}\text { Protein } \\
\text { Conc (g/L) }\end{array}$ & $\begin{array}{c}\text { Total } \\
\text { Protein (g) }\end{array}$ & $\begin{array}{c}\text { Enzyme } \\
\text { Activity } \\
\text { (U/L) }\end{array}$ & $\begin{array}{c}\text { Total } \\
\text { Activity U }\end{array}$ & $\begin{array}{c}\text { Specific } \\
\text { Activity (U/ } \\
\text { mg) }\end{array}$ & $\begin{array}{c}\text { Fold of } \\
\text { Purification }\end{array}$ & $\begin{array}{c}\text { Yield 100 } \\
\text { \% }\end{array}$ \\
\hline Serum & 0.0051 & 68.4 & 0.348 & 77 & 0.392 & 1.126 & 1 & 100 \\
\hline $\begin{array}{l}\text { Precipitationby } \\
\text { Ammonium sulphate 60\% }\end{array}$ & 0.0047 & 32.6 & 0.153 & 60 & 0.282 & 1.843 & 1.63 & 71.9 \\
\hline Dialysis & 0.0038 & 18.2 & 0.069 & 64 & 0.243 & 3.521 & 3.1 & 61.9 \\
\hline $\begin{array}{l}\text { Gel FiltrationSephadex } \\
\text { G-150 }\end{array}$ & 0.0032 & 2.1 & 0.006 & 66 & 0.211 & 35.166 & 31.2 & 53.8 \\
\hline
\end{tabular}

The approximate molecular weight of the protein bundle produced when the serum resulting from the dialysis step was passed into the separation column that contains the gel of the type sephadex G-150 and the molecular weight was The enzyme had limits (371000) Dalton For healthy subjects, also for patients with HCV the approximate molecular weight of the enzyme was about (346000) Dalton approximately, as well as for patients with HBsAg, the approximate molecular weight of the enzyme was approximately (316000) Dalton .These values were taken from the Figures 4,5,6.

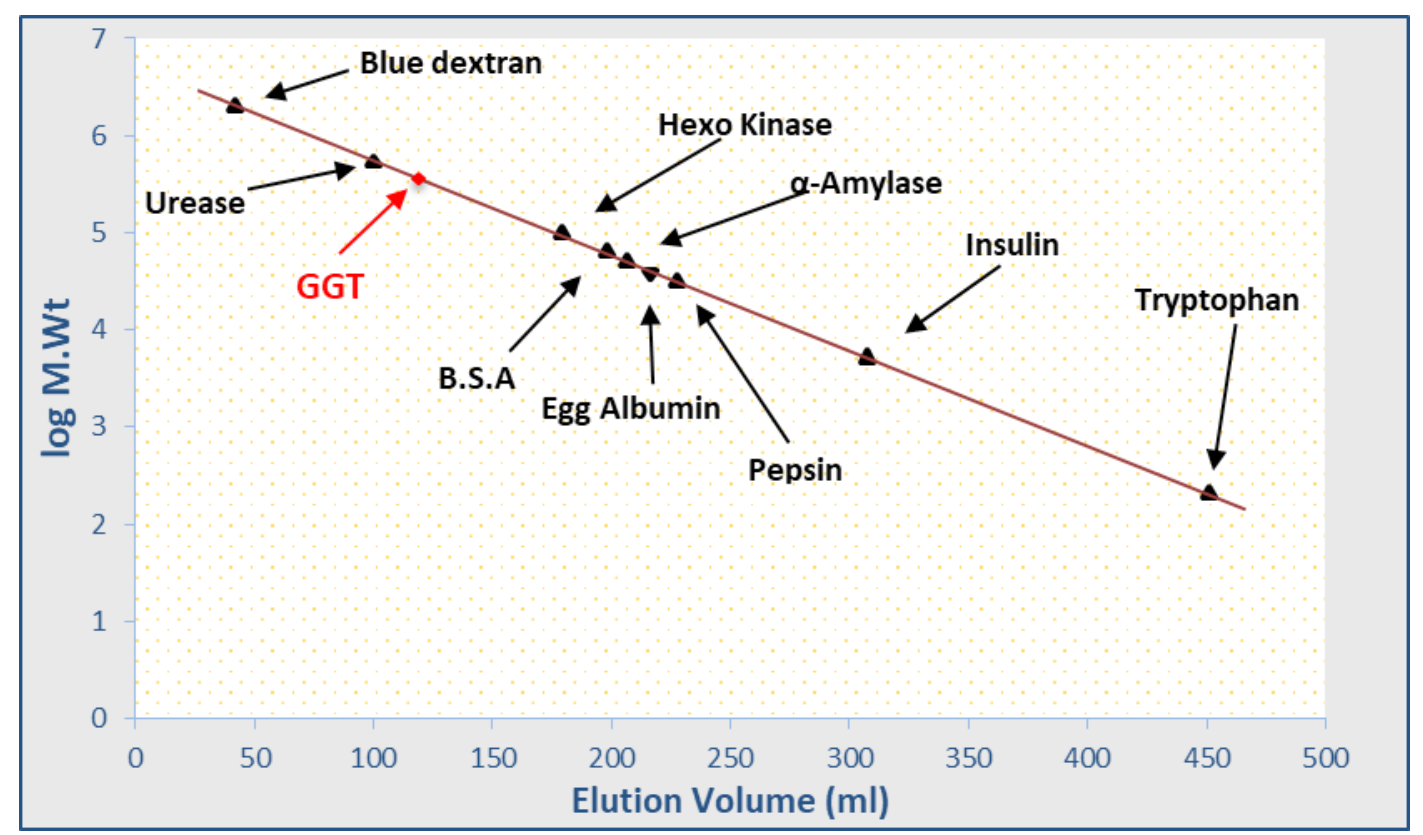

Figure 4: Standard curve for estimating the approximate molecular weight of the GGT enzyme using a sephadex G-150 gel-containing separator column for healthy subjects. 


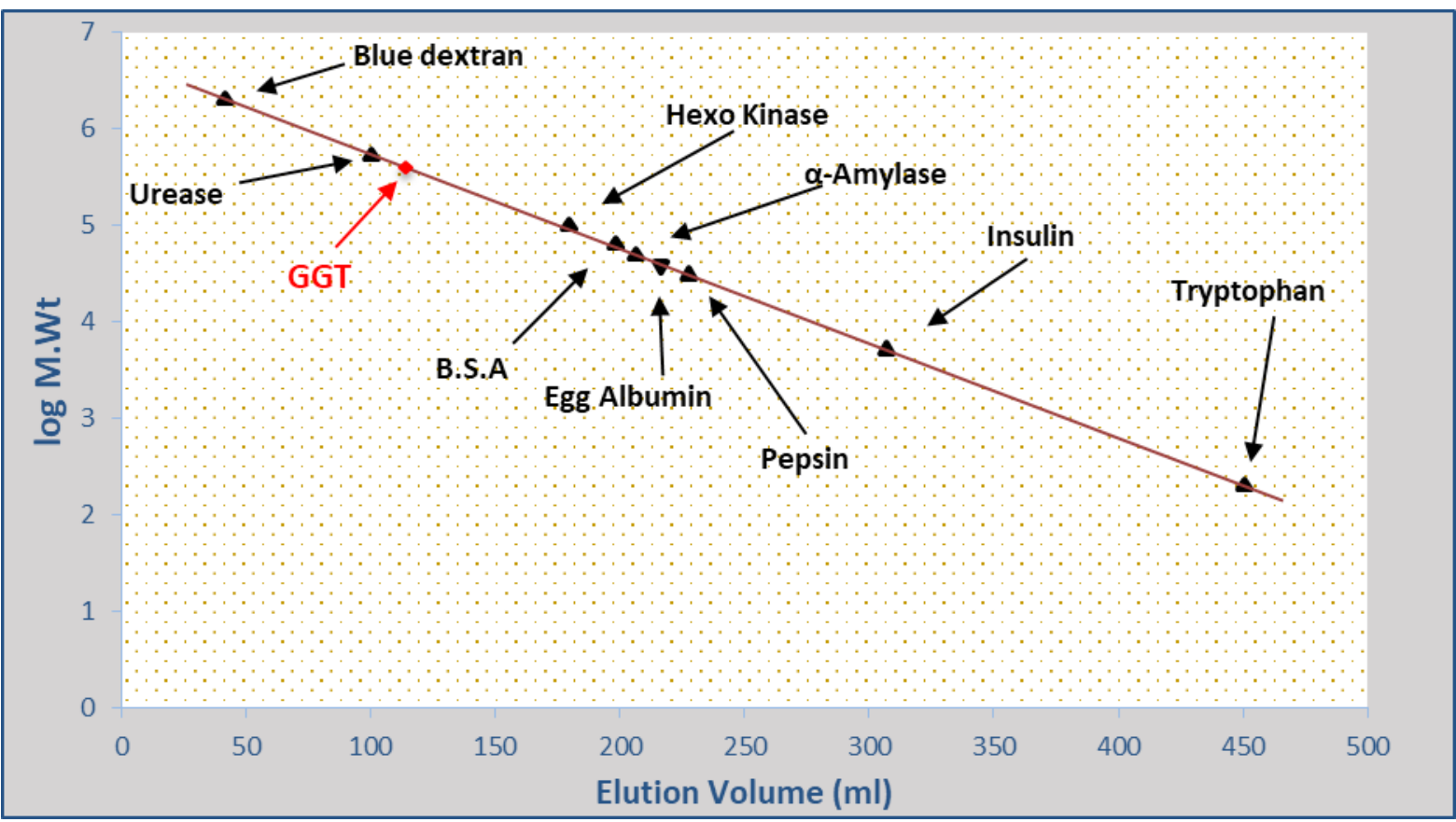

Figure 5: Standard curve for estimating the approximate molecular weight of GGT enzyme using a gelcontaining separation column sephadex G-150 for viral hepatitis $C$.

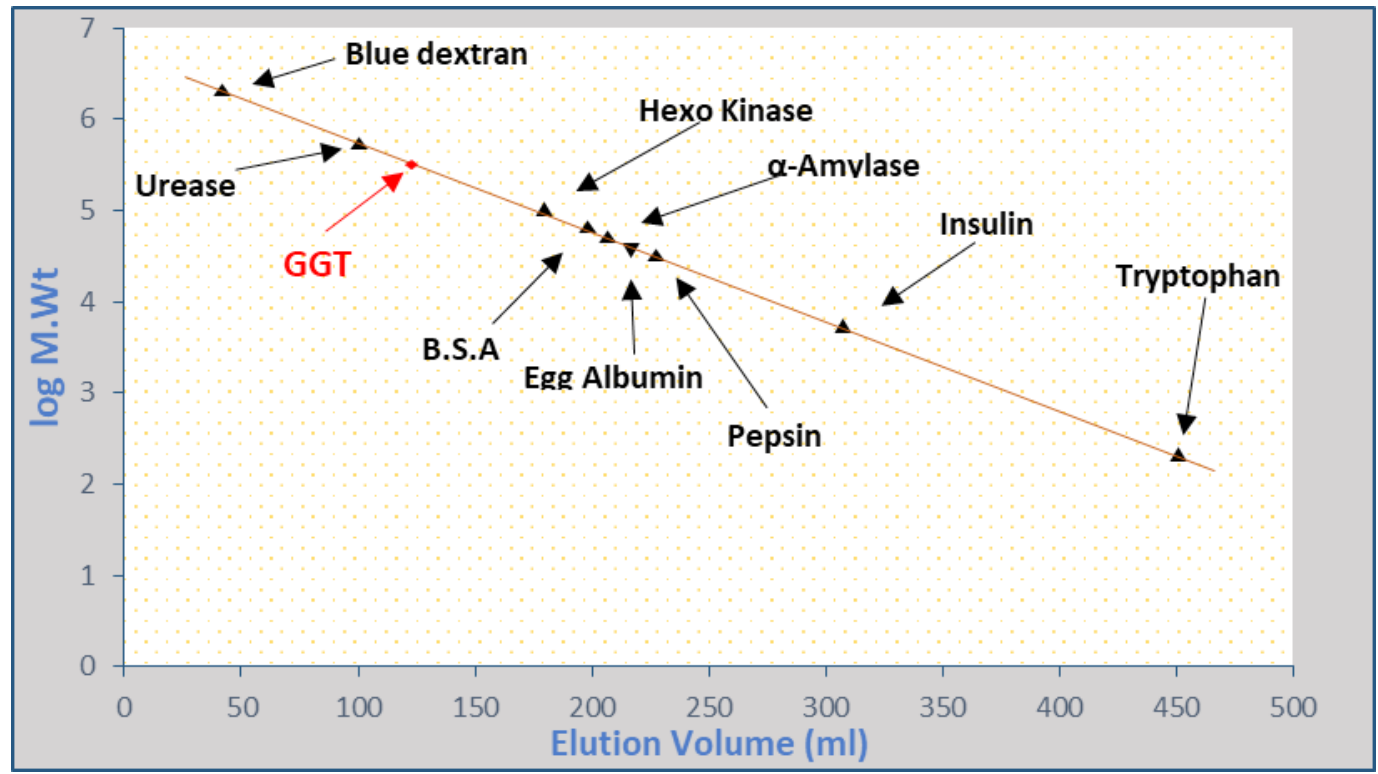

Figure 6: Standard curve for estimating the approximate molecular weight of GGT enzyme using a gelcontaining separation column sephadex G-150 for HBsAg patients.

The molecular weight of the GGT enzyme was determined by the method of electrophoresis in the presence of sodium dodecyl sulfate (SDS-PAGE). This method is widely used and is used in the process of separating large biomolecules such as enzymes, proteins and nucleic acids, where the enzyme is treated with sodium dodecyl sulfate, which works to break down The protein gives chains of different sizes surrounded by particles of negatively charged sodium dodecyl sulfate, which removes the original charge of the protein, so these chains migrate to the positive electrode as the movement of the protein in the gel depends on the charge it carries mainly and then depends on the size and shape of the protein, Figure 7 shows the shape of the GGT enzyme bundle when migrated with standard solutions of known molecular weight 16,17 . and in comparison between 
the GGT enzyme package and the standard compound packages, it was found that the molecular weight of the purified GGT enzyme from the sera of $\mathrm{HCV}$ patients and HBsAg is (68 K.D), and this is consistent with the findings of previous research ${ }^{18-21}$.

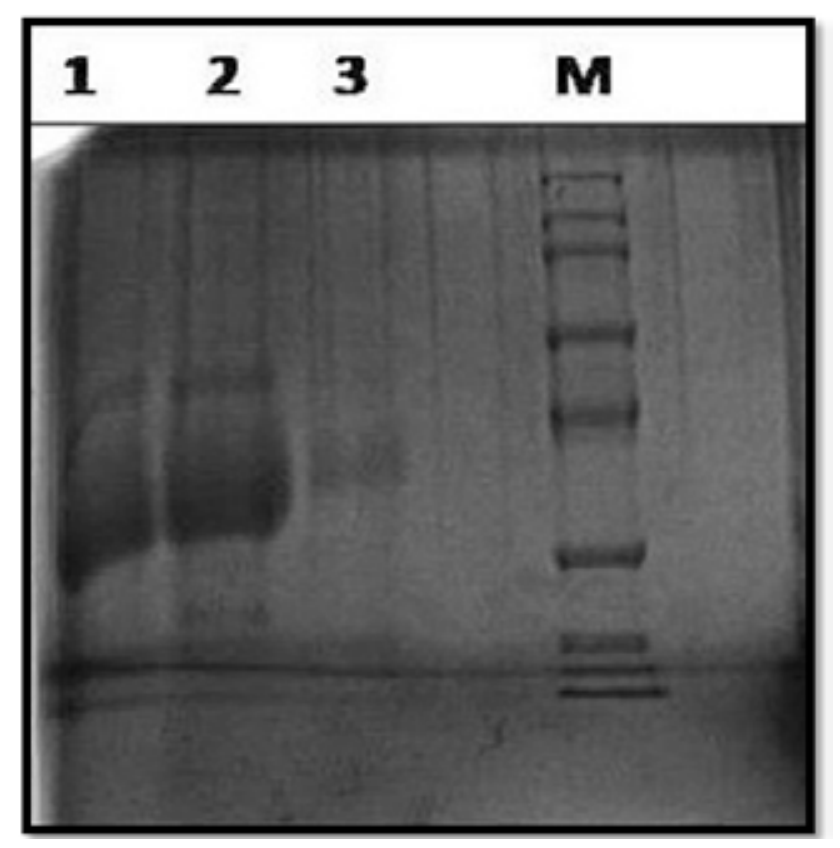

Figure 3-9: Electrophoresis of purified GGT enzyme to find approximate molecular weight compared to standard solutions. (1 : Healthy, 2 : HCV, 3 : HBV, $\mathrm{M}$ : protein marker)

\section{Discussion}

The increase in the GGT rate in hepatitis B and $\mathrm{C}$ patients compared to the control group indicates a difference, and this gives evidence of the importance of GGT activity as a reliable marker for long-term (HCV, $\mathrm{HBV}$ ) infection. It is considered as an independent indicator for both viral response and clinical outcome among patients with advanced liver disease due to hepatitis $\mathrm{C}$ and $\mathrm{B}$. These general results in this research are consistent with previous work and are supported by many studies. Increased GGT activity is observed in all forms of liver disease especially in blockage of bills within or after the liver ${ }^{22}$. In addition to increasing the level of the enzyme in cases of high triglycerides and liver disease. The factor of excessive alcohol consumption ${ }^{23}$. Previous studies ${ }^{24-27}$ showed an increase in the level of GGT activity in all patients with viral hepatitis B and $\mathrm{C}$ and most importantly, all of them showed a chronic increase in GGT, so it remained elevated repeatedly for a long time after the ALT level had returned to normal, as it is a closely related marker for predicting severity and GGT has been shown to have greater predictive significance than ALT or AST. Therefore, the association of GGT to any clinical point of treatment or liver disease in patients with viral hepatitis and liver cancer over relatively longer periods. And among (RuidanZheng et al) and (Rui Huang) ${ }^{28,29}$, the levels of ALT, AST, and GGT were significantly higher in patients with hepatitis B virus type, the GGT levels reached about 8 times higher than the limit. Normal highest and a significant positive association was found between serum GGT levels and serum ALT levels in chronic hepatitis B patients. Previous studies ${ }^{30-36}$ showed that the level of ALT, AST, and ALP in acute infection was higher than that in patients with chronic hepatitis . Previous literature indicated that GGT was purified from Helicobacter pylori from the gastric mucosa ${ }^{37}$, Bacillus subtilis SK1 $1.004{ }^{38}$, human kidney ${ }^{39}$ and human liver ${ }^{40}$, and with However, there is no evidence to suggest isoGGT enzyme purification in the serum of patients with hepatitis $\mathrm{B}$ and $\mathrm{C}$. The molecular weight of $68 \mathrm{KDa}$ found in this study is consistent with previous research ${ }^{41-44}$. All enzymes operate at an ideal $\mathrm{pH}$ that results in a change in the hydrogen ion concentration ${ }^{45}$. Any change in $\mathrm{H}+$ reduces the activity of the enzymes ${ }^{46}$. The $\mathrm{pH}$ can affect the activity of the enzyme due to the difference in its nature and chemical structure in addition to the presence of different ionic groups carried by the enzyme ${ }^{47}$. as the enzyme has a complex three-dimensional configuration that plays a role in the creation and functioning of the enzyme's active site ${ }^{48}$.

Financial Disclosure: There is no financial disclosure.

Conflict of Interest: None to declare.

Ethical Clearance: All experimental protocols were approved under the Kirkuk University and all experiments were carried out in accordance with approved guidelines.

\section{References}

1. Fujii H. "Frequently abnormal serum gammaglutamyltransferase activity is associated with future development of fatty liver: a retrospective cohort study.2020.

2. Finidori J. In vitro biosynthesis and membrane insertion of gamma-glutamyltranspeptidase." Journal of Biological Chemistry 259.8 (1984): 4687-4690. 
3. Bulusu, Sudha, and Manisha Sharma. "What does serum $\gamma$-glutamyltransferase tell us as a cardiometabolic risk marker?." Annals of clinical biochemistry.2016; 53.3: 312-332.

4. Gonzales E. "MYO5B mutations cause cholestasis with normal serum gamma-glutamyltransferase activity in children without microvillous inclusion disease.” Hepatology.2017; 65.1: 164-173.

5. Kasapoglu B. "Role of GGT in diagnosis of metabolic syndrome: a clinic-based cross-sectional survey." Indian Journal of Medical Research.2010; 132.1.

6. Hanigan, Marie H., and Henry F. Frierson Jr. "Immunohistochemical detection of gammaglutamyltranspeptidase in normal human tissue." Journal of Histochemistry \& Cytochemistry.1996; 44.10: 1101-1108.

7. Warren RM, SChng, RC Butler. Functional characteristics of New Zealand wheat rhizosphere Pseudomonas fluorescens isolates and their potential to inhibit invitro growth of Gaeumannomycesgraminisvartritici." New Zealand Plant Protection.2016; 69: 48-56.

8. Goldberg M. "Structural, functional, and clinical aspects of $\gamma$ glutamyltransferase." CRC critical reviews in clinical laboratory sciences.1980; 12.1: $1-58$.

9. Whitfield JB. "Gamma glutamyltransferase." Critical reviews in clinical laboratory sciences.2001; 38.4: 263-355.

10. Szasz G. A kinetic photometric method for serum gamma-glutamyltranspeptidase. Clinical Chemistry.1969; 15: 124-136.

11. Schacterle GR, Pollack RL. A simplified method for the quantitative assay of small amounts of protein in biological material. Anal. Biochem. 1973; 51: 654-55.

12. Tietz NW. Textbook of Clinical Chemistry, $3 \mathrm{~d}$ Ed. C.A. Curtis, E.R. Silverman, L.M., Christensen R. H. 1995; 523-524.

13. Saleh, Sayran S, Luay A, Lelas F. "Isolation of Acetylcholinesterase Enzyme from Cerebrospinal Fluid of Healthy and Hydrocephalus Disease Patients' Children in Mosul City.2000.

14. Morris CJ, Morris P. Separation method in biochemistry. 2nd ed ., pitman publishing.1976; 442 .
15. Laemmli K. Cleavage of structural proteins during the assembly of the head of bacteriophage T4." Nature.1970; 227.5259: 680-685.

16. Blackshear, Perry J. Systems for polyacrylamide gel electrophoresis." Method in enzymology. Academic Press, 1984;104: 237-255.

17. Roy K, NSenthilK, GGurusubramanian. "Proteinsstructure, properties and their separation by SDSpolyacrylamide gel electrophoresis." Sci Vis 2012; 12.4: 170-181.

18. Shaw LM. "Electrophoretic, kinetic, and immunoinhibition properties of gammaglutamyltransferase from various tissues compared." Clinical chemistry.1980; 26.11: 15231527.

19. Liu Y. "Purification and characterisation of two enzymes related to endogenous formaldehyde in Lentinulaedodes." Food chemistry 2013; 138.4: 2174-2179.

20. Tate, S. S., and M. ELIZABETH Ross. "Human kidney gamma-glutamyltranspeptidase. Catalytic properties, subunit structure, and localization of the gamma-glutamyl binding site on the light subunit." Journal of Biological Chemistry.1977; 252.17 : 6042-6045.

21. Shaw LM, JW London, LE. Petersen. "Isolation of gamma-glutamyltransferase from human liver, and comparison with the enzyme from human kidney." Clinical chemistry 24.6 (1978): 905-915.

22. Lee DH, Buijsse B, Steffen L, Holtzman, J. Association between Serum Gamma-Glutamyl Transferase and Cardiovascular Mortality Varies by Age: The Minnesota Heart Survey. European Journal of Cardiovascular Prevention and Rehabilitation.2009; 16: 16-20.

23. Ess M, Mussner-Seeber C, Mariacher S. Gamma Glutamyl Transferase rather than Total Bilirubin Predicts Outcome in Chronic Heart Failure. Journal of Cardiac Failure.2011; 17: 577-584.

24. Simon N, Couroucé A, Lemarrec N. A twelve year natural history of hepatitis $\mathrm{C}$ virus infection in hemodialyzed patients. Kidney international.1994; 46(2): 504-511.?

25. Fraquelli M. "Etiology-related determinants of liver stiffness values in chronic viral hepatitis B or C." Journal of hepatology.2011; 54.4: 621-628.

26. Paolicchi A. "Gamma-glutamyltransferase in fine-needle liver biopsies of subjects with chronic 
hepatitis C." Journal of Viral Hepatitis. 2005; 12.3: 269-273.

27. Everhart E, Elizabeth C. "Association of $\gamma$ glutamyltransferase (GGT) activity with treatment and clinical outcomes in chronic hepatitis C (HCV).” Hepatology. 2013; 57.5: 1725-1733.

28. Zheng R. "Clinical and virological characteristics of chronic hepatitis B patients with hepatic steatosis." International Journal of Medical Sciences. 2013; 10.5: 641 .

29. Huang R. "Association of serum gammaglutamyltransferase with treatment outcome in chronic hepatitis B patients." World Journal of Gastroenterology: WJG. 2015; 21.34: 9957.

30. Abid AJ, Salih AM. Some immunological and biochemical aspects for hepatitis B virus detection. J Babylon University 2013;(21) :2744-53.

31. Al-Hilli HA, Ghadhban JM. Prevalence of serological markers of HBsAg and HCV antibodies among blood donors and certain risk groups. J Fac Med Baghdad 2000;42(1):45.

32. Mauss S, Berg T, Rockstroh J, Sarrazin C, Wedemeyer H, Kamps BS. Hepatology- A Clinical Textbook. 4th ed. Frankfurt: Flying Publisher; 2017:92-300.

33. Ali SS, Ali IS, Aamir AH, Jadoon Z, Inayatullah S. Frequency of hepatitis $\mathrm{C}$ infection in diabetic patients. J Ayub Med Coll Abbottabad 2007; 19(1):46-9.

34. Mehta SH,Brancati FL,Strathdee SA. Hepatitis $\mathrm{C}$ virus infection and incident type 2 diabetes.J Hepatol 2003;38 (1); 244-2.

35. Lee MH, Yang HI, Chen CJ. Long-term health outcomes of chronic hepatitis $\mathrm{C}$ patients: A review of findings from REVEAL-HCV cohort study. Biomed 2012;11(3): 99-107.

36. Al-Haidary BA, Abdul-Kareem S, Azziz FN, AlAkaishi RJ, Al-Mousawy AZ. Viral load among the sera of Iraqi hepatitis $\mathrm{C}$ virus patients. Fac Med Baghdad 2007; 49(4):461-6.

37. Song J. "Purification and Characterization of Helicobacter pylori $\gamma$-Glutamyltranspeptidase." Journal of Bacteriology and Virology.2011; 41.4: 255-265.
38. Shuai Y. "Purification and characterization of $\gamma$-glutamyltranspeptidase from Bacillus subtilis SK11. 004." Journal of agricultural and food chemistry.2011; 59.11: 6233-6238.

39. Miller, STEVEN P., YOGESH CSATISH $\mathrm{K}$. "Studies of human kidney gammaglutamyltranspeptidase. Purification and structural, kinetic and immunological properties." Journal of Biological Chemistry 1976; 251.8: 2271-2278.

40. Goldberg M. "Structural, functional, and clinical aspects of $\gamma$ glutamyltransferase." CRC critical reviews in clinical laboratory sciences.1980; 12.1: $1-58$.

41. Mason, JE, Starke, R.D. and Van Kirk, J.E. (2010) Gamma-Glutamyl Transferase: A Novel Cardiovascular Risk Biomarker. Preventive Cardiology, 13, 36-41.

42. Ying L, Yan Y, Xiao-yu L. Purification and Characterization of Two Enzymes Related to Endogenous Formaldehyde in Lentinulaedodes . Food Chemistry.2013; 138: 2174-2179.

43. Tate S, Ross M. Human Kidney $\gamma$-Glutamyl Transpeptidase. The Journal of Biological Chemistry.1977; 252: 6042-6045.

44. Shaw L, London J, Petersen L. Isolation of Gamma Glutamyl Transferase from Human Liver and Comparison with the Enzyme from Human Kidney. Clinical Chemistry.1978; 24: 905-915.

45. Lehninger Albert L, David L. Nelson, and Michael M. Cox. Lehninger principles of biochemistry. Macmillan, 2005.

46. Chrisblosser A. Effects of Temperature, pH, Enzyme Concentration, and Substrate Concentration on Enzymatic Activity. StudyMode.com. 2012; 10: 557.

47. Zheng H. "Effects of $\mathrm{pH}$, temperature and enzymeto-substrate ratio on the antigenicity of whey protein hydrolysates prepared by Alcalase.” International dairy journal. 2008; 18.10-11: 1028-1033.

48. Liu Y. "Purification and characterisation of two enzymes related to endogenous formaldehyde in Lentinulaedodes." Food chemistry. 2013; 138.4: 21742179. 